\title{
Stem Cells Research: Therapeutic Potentials and Ethical Issues from Islamic Perspective
}

\author{
Che Anuar Che Mohamad ${ }^{1}$ and Abdurezak Abdullahi Hashi ${ }^{2}$ \\ ${ }^{1}$ Kulliyyah of Pharmacy, International Islamic University Malaysia ${ }^{2}$ Kulliyyah of Science, International Islamic \\ University Malaysia
}

\begin{abstract}
The advancement in human stem cell research has promised a viable alternative treatment for a range of 'incurable diseases' such as neurological diseases. To date, several studies have documented substantial evidences on the therapeutic properties of stem cells in promoting repair in different diseases including common neurological disorders i.e. ischaemic stroke and spinal cord injury. However, the progress of stem cell research has been surrounded by ethical issues which largely due to the usage of human embryos as one of the sources. These embryonic stem cells which originally derived from human embryo of aborted foetus or already existing human embryonic stem cells (hESCs) lines, has sparked an intense moral and religious argument among people of various faith, including Muslim community. From the therapeutic point of view, amongst the currently available stem cells, hESCs show the greatest potential for the broadest range of cell replacement therapies and are regarded as the most commercially viable. This review focuses on the major ethical issues, particularly to Muslim community, related to human embryonic stem cells research with special emphasis on the moral status of the embryo and the beginning of life according to the Islamic ethics and rulings. In this paper, we also discuss some ethical positions towards embryonic stem cell research in the Islamic world, including official regulations existing in some Muslim countries. We examine the justification and the necessity on the usage of hESCs following the newly discovered Induced Pluripotent Stem Cells (IPSCs) in the laboratory. In addition, we supplement the discussions with the general views and positions from the other two Abrahamic religions i.e. Christianity and Judaism.
\end{abstract}

KEYWORDS: Stem cells, Human embryonic stem cells (hESCs), Islam and ethic

\section{INTRODUCTION}

The advancement in the stem cell research has promised a viable alternative treatment for a range of 'incurable diseases' like several different neurological diseases. The emergence of stem cell research has attracted interest of people from various backgrounds as it is regarded as one of the most promising tools for medical treatment. The overwhelming interest on the stem cell research is largely attributed to its potential to be used as a treatment tool for treating various diseases which have been long regarded as incurable, including certain neurological diseases where therapies are at the moment largely palliative and inefficient. The absence of efficient therapy for those diseases has created a significant burden in the health sector as large numbers of patients who succumb to it usually require a long duration palliative care.

To date, several studies have documented substantial evidences on the therapeutic properties of stem cells in promoting repair in various diseases including certain neurological disorders i.e. ischaemic stroke and spinal cord injury. These two diseases are among the diseases which are associated with significant level of disability to the

Che Anuar Che Mohamad

Department of Basic Medical Sciences,

Kulliyyah of Pharmacy,

nternational Islamic University Malaysia,

Kuantan Campus.

Email: dranuar@iium.edu.my sufferers. There is a certain type of stem cells i.e. haematopoietic stem cells that has been successfully translated into standard clinical treatment in the treatment of certain blood and immune system disorders. However, the progress of stem cell research has been surrounded by many ethical issues and one of them is due to the usage of human embryos as one of the sources. These embryonic stem cells which originally derived from human embryo of aborted foetus or already existing human embryonic stem cells (hESCs) lines, has sparked an intense moral and religious argument among people of various faith, including Muslim community. From the therapeutic point of view, hESCs have displayed the greatest potential for the broadest range of cell replacement therapies and were regarded as the most commercially viable to be developed into becoming treatment tools.

There are various advantages of this type of stem cells such as the capacity to be propagated in vitro almost indefinitely as opposed to the adult stem cells, thus offering the possibility of unlimited supply of cells therapy. This review focuses on the major ethical issues related to human embryonic stem cells research with special emphasis on the moral status of the embryo and the beginning of life according to the Islamic ethics and rulings. The Islamic ethical positions towards embryonic stem cell research in the Islamic world, including official regulations existing in some Muslim countries are discussed. On top of that, we examine the justification and the necessity to further research on hESCs following the later discovery of the less 
ethical Induced Pluripotent Stem Cells (IPSCs) in the laboratory. The general views and positions from the other two Abrahamic religions i.e. Christianity and Judaism are also covered.

\section{Features and Therapeutic Potentials of hESCs}

Historically, the 'stem cell' terminology is adopted from the nomenclature used in the haemopoietic system which refers to a population with the ability for extended self renewal and generation of multiple cell lineages. ${ }^{1} \mathrm{~A}$ later definition of stem cells defines them as "a group of cells which have the ability to proliferate, self maintain and produce a differentiated and functional progeny". ${ }^{2}$ A more widely accepted definition of stem cells is that they are 'cells that exhibit the ability of self renewal and differentiation into mature cells'.

Stem cells are mainly classified based on their sources or origins and hESCs is one of them. As mentioned earlier, hESCs is the most exciting group of stem cells in view of its greatest therapeutic potential. They are originally derived from the inner cell mass (ICM) of preimplantation embryos and was first successfully isolated and established from human embryos of IVF clinics in $1998^{3}$ at the University of Wisconsin. The discovery has led to tremendous discussions concerning the potential application of human embryonic stem cells in transplant surgery and regenerative medicine, as well as ethical issues related to embryo destruction. ${ }^{4}$ Despite the associated ethical issues over the usage of the embryos, the promise of a virtually unlimited source of different cell types for cell therapies coupled with the use for drug screening and development studies has resulted in a considerable progress in hESCs research and clinical trials.

Principally, hESCs are characterized by two unique features i.e. 1) the ability of unlimited self-renewal and 2 ) the capacity to differentiate into all lineages. Additionally, they can also be grown in virtually unlimited numbers and able to retain high telomerase activity (an enzyme which causes the cells to become immortal in culture without inducing any malignant transformation). ${ }^{5}$

One of the approaches favoured by the scientists is to derive differentiated cells from hESCs depending on the targeted system. Several studies have demonstrated that human ESCs can be differentiated into neuronal or glial cells with some studies reporting that they support regeneration and remyelination after $\mathrm{SCl}^{6}{ }^{6}{ }_{7}^{7}$ This approach enhances the therapeutic potential in treatment process while minimising the risk of tumorigenesis as compared to direct application of hESCs into the affected area.

Following the first clinical trial of $\mathrm{hESC}$-derived oligodendrocytes progenitor cells GRNOPC 1 in 2009 by Geron Corporation, there have been several other ongoing clinical trials involving hESCs. The preliminary results of these multiple clinical trials mainly demonstrated the safety of hESC-based therapies with limited evidence of improvement. ${ }^{8}$ Otherwise it suggests the promising value of hESCbased therapies to be further developed as potential candidate for treatment of 'incurable diseases'.

\section{Human Embryonic Stem Cells (HESCs): Ethical Issues and Islamic Positions}

The human stem cell research has long sparked a heated moral, political, and religious debate among people at all levels of public life ${ }^{9}$, particularly following the first derivation of hESCs lines by Thompson et al in $1998 .{ }^{3}$ In certain countries like USA, stem cell research has been hampered by the debate which has become entangled with the American abortion debate (Annas et al., 1999). ${ }^{10}$ This association has indirectly delayed the approval to conduct the research involving hESCs. The issue on the moral standing of human embryos has led to either prohibition or restriction of work related to hESC in some countries.

The main reason of controversy is largely due to the sources of hESCs which are either from the human embryos or the reproductive tissues of aborted foetuses. ${ }^{10}$ This has led it to be associated with an act of abortion while most of the current available research on $\mathrm{hESCs}$ are derived from either already existing human embryonic stem cell lines, embryos that are left after in vitro fertilization (spared embryos) or embryos created by means of somatic cell nuclear transfer technique. ${ }^{11}$ Relatively, deriving $\mathrm{hESCs}$ from already existing stem cell lines to be used in research and therapy development is less controversial and is considered less ethical as compared to spared embryo.

The moral status of the embryo is the main issue to be resolved and it is closely related when life of a human being starts. There is a great debate of whether to regard the embryo as a human being, or a non living object, or as something in between. The truth of the beginning of life in the human embryo is yet or may never be answered by science and the closest evidence so far could be referred to the development and completion of the nervous system. ${ }^{12}$ \& 13 The absence of widely accepted definition of life in science has contributed to endless debate in the legal status of the embryo. In the modern secular world, the legal status of the embryo still remains highly debatable and the unborn have no definite status in a court of law. In addition, many legal systems do not recognize foetuses or embryos as being entitled to the same rights as those who have been born. ${ }^{14}$ While science has yet to come up with a consensus on when life begin, the three religions have discussed this question for thousands of years in their texts.

From the religious point of view, Judaism and Islam have supported their beliefs on the beginning of life by referring to their specific religious texts. In Judaism, it is stated that the embryo becomes a 
human being after 40 days from conception and there is no official moral imprint recognized until day 40 \& 12 , which means that any beneficial research using the embryo prior to that time is permissible. ${ }^{12}$ One Jewish religious law expert (halachah), Professor Laurie Zoloth continues to support the practice of using embryonic stem cells to save lives and to heal. ${ }^{9}$ She justified the manipulation of an embryo is not considered as a murder based on the Halachic law as the goal is to heal and to improve healthcare.

In Islam, there is no specific delineation of the beginning of life from both primary sources i.e. Quran and hadith. In fact, the followers are reminded of human's limitation on the knowledge of soul (ruh) as mentioned in in chapter 17, verse 85.

"And they ask you (Muhammad) concerning the soul/spirit (Ruh). Say: the Ruh is one of the things, the knowledge of which is only with my Lord. And of knowledge, you have been given only a little." $(17: 85)$.

However, there are few evidences that suggest a more acceptable position for the Muslims. The status of the embryo is discussed in Chapter 23, verse $12-14$ of the Quran which indicated that a foetus is perceived as a human life in a later developmental process as the Quran uses the phrase "thereafter we produced him another creature".

"We created (khalaqna) man of an extraction of clay, then we sent him, a drop in safe lodging, then we created of the drop a clot, then we created of the clot a tissue, then we created of the tissue bones, then we covered the bones in flesh; thereafter we produced it as another creature. So blessed be God, the best of creators" (23:12-14).

Another textual evidence indicating the sign of the beginning of life through ensoulment is taken from the hadith:

"Each of you is constituted in your mother's womb for forty days as drop of matter (nutfah), then it becomes a blot clot (alaqah) for an equal period, then a blob (mudghah) for another forty days, and then the angel is sent and he breathes life into him" (Bukhari and Muslim).

While there are differences of opinion among Muslim scholars in determining whether ensoulment occurs at 40 or 120 days, evidence from the abovementioned hadith has been the basis for majority of the Muslim scholars to justify permissibility of using an embryo for stem cell research as the embryo before the ensoulment is not yet considered a person. ${ }^{12,13,15 \& 16}$ The same evidence also supported a clear distinction between actual life after the ensoulment and potential life prior to it, promoting more protection for actual life as compared to potential life. ${ }^{17}$ Therefore, manipulating the embryo at blastocyst stage (regarded as potential life) to develop a cure for diseases that are still poorly treated in actual life is considered lawful. This view is based on the resolution of the Figh Council of Muslim World
League which takes the majority view that "ensoulment" takes place 120 days after fertilization. ${ }^{18}$ Another statements by the Fiqh Council of Muslim World League on stem cell research was published in 2003 where the council stated that it is acceptable to obtain stem cells and use for the treatment or research from the following possible sources: 1) Adults, 2) Children, 3) The placenta and the umbilical cord and 4) Spontaneously aborted foetuses. The permission however is subjected to the earlier consent from the donor himself or the parents/guardians, apart from absence of harm during the procedure of derivation. The National Fatwa of Malaysia in 2005 has further declared that the use of surplus embryos for stem cell research is permissible, on top of the other sources listed by the Muslim World League statements. ${ }^{19}$

It is however important to note that despite the agreement of the majority that actual life begins at 40 or 120 days after conception, all Muslim intellectuals agreed that the embryonic life is to be respected even before ensoulment, hence permissibility for hESCs research does not represent an absolute permissibility to manipulate the embryos freely. Careful considerations and all possible precautions need to be taken to justify the necessity to conduct research involves hESCs.

In Christianity, St Basel the Great stated that the embryo must be treated as a human person regardless of the stage of development. ${ }^{12}$ The Catholic, Orthodox (Greek/Coptic) and conservative Protestant churches believe that ensoulment occurs at the moment of fertilization (conception). Therefore, the embryo has the right to life and any destructive intervention on the human embryo like hESCs derivation is not justifiable for whatever reason. This position is reflected in one of the declaration by Vatican in year 2000 that the act of removing the inner cell mass from an embryo was "a gravely immoral act and consequently is gravely illicit". 9 Otherwise, generally they regard hESCs research (derivation and use) is unethical and illegal and even as homicide if involves the wilful destruction of human embryos. ${ }^{20}$

These three religious beliefs have led into two opposing views. The view against human embryonic stem cell research is based on the belief that the embryo deserves extreme protection and should not be used for research. This group, which is largely influenced by their Christian beliefs, consider the status of the embryo to be equivalent to a human being from the point of fertilization. ${ }^{14}$ The group that is in line with the Islamic and Jewish position supports the human embryonic stem cell research as they consider the early pre-implantation blastocyst as not to be a definite life. They further justified the for hESCs research as the option of a lesser evil to bring about a greater good. ${ }^{9}$ To them also, the definite protection of human embryos only begins after several weeks of natural development. ${ }^{14}$ The view of the second group is shared by many 
scientists, patients, and physicians, as well as moderate philosophers and theologians. ${ }^{9}$ What makes the second view acceptable is that the aim of using the embryo must be for the good of mankind. Furthermore, this moderate view could potentially resolve the religious barrier while the first group's opinion may hamper the critical therapeutic discovery based on hESCs.

Despite some differences in determining the beginning of life between Christianity and the other two religions, it is important to note that all three Abrahamic religions share similar views in defining human life as sacred. This view forms a strong foundation in designing the regulations for human embryonic stem cell research, without violating the noble status of the embryo.

From the technical point of view, those who support the use of spare embryos consider donation of spare embryos from IVF for use in important medical research, is ethically superior and more defensible as compared to destroying them or blindly cryopreserving them. ${ }^{10}$ They even argue that if this practice is not permissible to treat incurable diseases, sacrificing them to treat infertility is far more unjustifiable and unethical. ${ }^{11}$ The current accepted position regarding the use of spare embryos is that they should only be used for therapeutic research to treat serious human diseases which according to the Islamic jurisprudence falls under the principle of dharurah (necessity) and rukhsoh (concessionary law).

\section{Human Induced Pluripotent Stem Cells (HIPSCs) as Alternative to HESCs}

The controversy about the derivation and use of hESCs led scientists to look for a less ethically sources but maximally useful stem cells. In year 2007, the team of scientists had developed a method to reprogramme mature human cells to resemble pluripotent stem cells. These cells are referred as human induced pluripotent stem cells (HiPSCs), adult cells which have been reprogrammed to display certain unique feature of hESCs such as the ability to differentiate into any tissue cell type. Human Induced pluripotent stem cells (HiPSCs) are an interesting alternative to hESCs as they are free of most ethical issues related to hESCs, as well as reducing the risk of immunological rejection yet offering the unique features hESCs. They are produced from human fibroblasts by introducing Sox2, Klf4, Oct3/4 and c-Myc in culture. ${ }^{21}$ Human iPSCs have been shown to be similar to hESCs in morphology, proliferation, surface antigens, gene expression, epigenetic status of pluripotent cellspecific genes and telomerase activity. ${ }^{21}$ Additionally, they have also been shown to be able to differentiate into functional nervous cells such as neurons, astrocytes and oligodendrocytes. ${ }^{22}$

HiPSCs have been shown to be equally useful to hESCs for addressing certain research questions but there are few significant limitations noted. Those limitations have raised the doubt on their potential to absolutely replace hESCs. Amongst them are related to the safety and efficacy ${ }^{23}$ of the methods involved in producing hiPSCs. One of the most recent advances in inducing pluripotency using STAP has been questioned as their results have not proven reproducible. ${ }^{24 \& 25}$ In addition to that, there is a critical need for a consent from the donor as iPSCs are derived from the somatic cells of identifiable individuals thus failure to do so will lead to a serious ethical issue. ${ }^{4}$ Beside, hiPSCs would not have the advantage of an "off the shelf" product in terms of allowing an early intervention since the cells would need to be re-programmed to iPSCs and further differentiated if necessary to fit the target interest.

In summary, the above issues highlighted the limitations of hiPSCs which undermine them to be the absolute replacement for hESCs. While the discovery of hiPCs cells was a great milestone in stem cell research, more researches are obviously required to discover whether they offer the same research and therapeutic values as hESCs.

\section{CONCLUSION}

In conclusion, there is a strong basis for furthering human embryonic stem cell research, given the insights from moderate religious points of view, including the Islamic view which given conditional permission to embryonic stem cells research and use. The permissibility has also considered the overwhelming and promising therapeutic properties of hESCs as well as the valid and critical therapeutic justification. There is a critical need for scientists, theologians and bioethicists to reconcile the conflicting views pertaining to the justifiable use of hESCs. Although scientists are the main players in developing stem cells research and therapy, they have to also rely on religious experts and authorities in forming an ethically sound opinion related to the hESCs. While science has yet to come up with a consensus on when life begin, the three Abrahamic religions have answers this question for thousands of years based on their textual analysis.

From the therapeutic point of view, hESCs remain as the most viable and promising type of stem cells even though research with candidates i.e. iPSCs and other highly multipotent stem cells are also expanding and progressing at their own pace.

\section{REFERENCES}

1. Fisher, LJ. Neural Precursor Cells: Application for the study and repair of the central nervous system. Neurobiology of Disease, 1997; 4:1-22.

2. Okano, H. Neural stem cells:progression of basic research and perspective for clinical application. Keio J Med, 2002;51:115-128

3. Thompson, JA; Itskovitz-Eldor, J; Shapiro, SS et al. Embryonic stem cell lines derived from human blastocyst. Science, 1998;282:11451147 
4. King, N. M., \& Perrin, J. (2014). Ethical issues in stem cell research and therapy. Stem Cell Research \& Therapy, 5(4), 85.

5. Coutts, M. \& Keirstead, H. S. Stem cells for the treatment of spinal cord injury. Exp

Neurol,2008; 209:368-77.

6. Keirstead HS, Nistor G, et al. Human embryonic stem cell-derived oligodendrocyte progenitor cell transplants remyelinate and restore locomotion after spinal cord injury. Journal of Neuroscience. 2005 ;25:4694-705.

7. Nistor GI, Totoiu MO, Haque N, Carpenter MK, Keirstead HS. Human embryonic stem cells differentiate into oligodendrocytes in high purity and myelinate after spinal cord transplantation. Glia. 2005;49(3):385-96.

8. Ilic D, Devito L, Miere C, Codognotto S. Human embryonic and induced pluripotent stem cells in clinical trials. British medical bulletin. 2015;116(1):19-27.

9. Scott CT. Stem cell now: A brief introduction to the coming medical revolution. Penguin; 2006

10. Annas, GJ; Caplan, A; Elias, S. Stem cells politics, ethics and medical progress. Nature Medicine, 1999; 5:1339-134.

11. Hug K. Sources of human embryos for stem cell research: ethical problems and their possible solutions. Medicina. 2005;41(12):1002-10.

12. Iftimae, O. Never Ending Story Human Embryonic Stem Cells Science and Bioethics. European Journal Of Science and Theology, 2005;1 (1):39-49.

13. Weckerly $M$. The Islamic view on stem cell research. and various cited therein) wwwcamlaw. rutgers. edu/publications/lawreligion/new_devs/RJLR_ND_56.pdf. 2011.

14. Dickens BM, Cook RJ. Ethical and legal approaches to 'the fetal patient'. International Journal of Gynecology \& Obstetrics. 2003;83:85-91.

15. Albar, M.A. (1992) Human Development as revealed in the Holy Quran and Hadith, Jeddah, Saudi Arabia: Saudi Publishing House

16. IMANA Ethics Committee. Islamic medical ethics: the IMANA perspective. Journal of the Islamic Medical Association of North America. 2005;37(1).

17. Fadel HE. Prospects and ethics of stem cell research: an Islamic perspective. Journal of the Islamic Medical Association of North America. 2007;39(2).

18. Sivaranam MAF, Mohd Noor SN. Ethics of embryonic stem cell research according to Buddhist, Hindu, Catholic, and Islamic religions: perspective from Malaysia. Asian Biomedicine, 2014;8:43-52.

19. Department of Islamic Development Malaysia. Ruling 口on Therapeutic Cloning and Stem Cell Research. 2005; http://www.e-

fatwa.gov.my/fatwa-kebangsaan/hukumpengklonan-terapeutik-dan-penyelidikan-selstem- stem-cell.

20. Isa M, Lokman M. Stem cells research: value, ethical and religious views. In: Cell and tissue culture: research and technology from Islamic perspective. IIUM Press, Kuala Lumpur, pp. 186-195. 2014

21. Takahashi, K., Tanabe, K., Ohnuki, M., et al. Induction of Pluripotent 21.Stem Cells from Adult Human Fibroblasts by Defined Factors. Cell,2007; 131:861-872

22. Miura K, Okada Y, Aoi T, Okada A, Takahashi K, Okita K, Nakagawa M, Koyanagi M, Tanabe $K$, Ohnuki M, Ogawa D. Variation in the safety of induced pluripotent stem cell lines. Nature biotechnology. 2009;27(8):743.

23. Pera MF: Stem cells: the dark side of induced pluripotency. Nature ,2011; 471:46-47.

24. Cyranoski D: Acid-bath stem-cell study under investigation. Nature 2014;10.

25. Obokata H, Wakayama T, Sasai Y, Kojima K, Vacanti MP, Niwa H, Yamato M, Vacanti CA: Stimulus-triggered fate conversion of somatic cells into pluripotency. Nature 2014; 505:641647.

26. Ilic D, Ogilvie C. Concise review: Human embryonic stem cells-what have we done? What are we doing? Where are we going?. Stem Cells. 2017; 35(1):17-25.

27. Shostak, S. (2006) Redefining stem cells. BioEssays Vol 28, 301-308

28. Trounson, A. (2006) The production and directed differentiation of human embryonic stem cells. Endocrine Reviews Vol 27, 208-219

29. Wan Muhamad, R; Alias, F; Jahn Kassim, PN; Husin, N (2016) The Doctrine of Sanctity of Life From The Islamic Perspective. Al-Shajarah Vol 21(1)23-48 